\title{
Рецензії
}

\section{РЕЦЕНЗІЯ \\ НА МОНОГРАФІЮ «ЦЕРКОВНО-ПОЛІТИЧНА ІСТОРІЯ РИМСЬКИХ ПАП» (автор М.Отрош)}

\author{
MONOGRAPH REVIEW \\ "CHURCH-POLITICAL HISTORY OF ROMAN POPES" \\ (author M. Otrosh)
}

У 2019-2020 рр. вийшла друком тритомна монографія «Церковно-політична історія Римських пап» доктора юридичних наук Отроша Михайла Івановича, знаного в академічній науці України фахівця у галузі міжнародного політичного права, в контексті комплексного дослідження теоретико-методологічних проблем функціонування Ватикану і Святого Престолу і діяльність Римських пап від першого століття християнства до його поділу (перший том, 390 с.), церковно-політичні трансформації від цього періоду до Вестфальського миру 1648 р. (другий том, 297 с.), церковно-політична діяльність Римських пап в Новій і Новітній історичні періоди (том третій, 510 с.). Трьохтомник вийшов під грифом Відділення релігієзнавства ІФ НАНУ, якому підняті теми тематично близькі. 
Рецензія на монографію «Церковно-політична історія...

В процесі опрацювання джерельного матеріалу, зокрема офіційних католицьких документів, які стосуються історії Римських пап та інституалізаційних структур Ватикану, автор дотримувався основоположних принципів академічного релігієзнавства: історизму, наукового об'єктивізму, позаконфесійності, плюралізму і толерантності.

Цим дослідженням доктора юридичних наук M.I. Отроша доведено, що Святий Престол як суб'єкт міжнародних відносин і міжнародного права має дипломатичні відносини майже 3200 країнами не лише християнської, а й з мусульманської, індуїстської, буддійської та іншої конфесійної ідентифікації. Взаємодіючи з усіма цими державами та 3 провідними міжнародними інституціями (зокрема $3 \mathrm{OOH} \mathrm{і} \mathrm{Свропейським} \mathrm{Союзом),} \mathrm{як} \mathrm{активний}$ депозитор збереження світового правопорядку Святий Престол налагоджує екуменічні взаємини 3 усіма християнськими церквами і міжконфесійних діалог з нехристиянськими світовими релігіями. Проекти наукової, освітньої, культурної, екологічної співпраці з різними країнами надають нового обрису сучасному інституту папства і функціонуванню Римським папам.

Водночас нагальна потреба в такому дослідженні й виданні тритомної церковно-політичної історії Римських пап і діяльності Ватикану є очевидною після встановлення 8 лютого 1992 р. дипломатичних відносин між Україною і Ватиканом.

Відтак, для відповідних українських інституцій набуває особливої актуальності правильне розуміння церковно-політичної історії Римських пап і вміле використання набутих знань для практичної діяльності.

Отже, тритомна монографія М.І.Отроша «Церковнополітична історія Римських папа»є першим у вітчизняній 
Українське релігієзнавство № 93

філософській (релігієзнавчій) науці комплексним дослідженням в якому показано, що Римський папа як глава Католицької церкви володіє одночасно духовним і світовим суверенітетом. Його служіння в інтересах Католицької церкви (духовна і світська складові) забезпечуються як ним особисто, так і системою підпорядкованих йому органів церковно-політичного характеру. У дослідженні історії понтифікатів значну увагу приділено аналізу сучасної католицької концепції захисту прав людини, внеску Святого Престолу у зміцнення міжнародної безпеки та врегулювання міжнародних конфліктів, розв' язання глобальних проблем міжнародного співтовариства. Святий Престол загальновизнаний суб'єкт міжнародного права. Окрім діяльності в ООН в ролі спостерігача, він бере активну участь в роботі майже 20 спеціалізованих установ в ООН, представлених в 14 установах безпосередньо від імені Державиміста Ватикан. Святий Престол присутній в організації ООН з питань освіти, науки і культури (ЮНЕСКО) зі спостережною місією, оскільки ці проблеми входять в коло постійних інтересів Ватикану. Святий Престол своїм моральним авторитетом підтримує діяльність Міжнародного агентства 3 атомної енергії і $є$ повноважним членом цієї організації. Особливу увагу Ватикан приділяє Свропі. Святий Престол є членом Організації безпеки і співробітництва в Свропі та інших міжнародних організацій.

Відтак, тритомна монографія доктора юридичних наук Отроша Михайла Івановича «Церковно-політична історія Римських пап» зацікавить і буде корисною для науковців, працівників відповідних органів державної влади та місцевого самоврядування, викладачів і студентів юридичних, історичних, філософських та богословських вузів i факультетів, а також для широкого кола читачів, яких 
Рецензія на монографію «Церковно-політична історія...

цікавлять питання релігійного фактору у сфері державноцерковних і міжнародно-правових відносин.

Петро Яроцький доктор філософських наук, професор, провідний науковий співробітник Відділення релігієзнавства Інституту філософії імені Г.С.Сковороди НАН України 